\title{
PELAKSANAAN STANDARD OPERATING PROCEDURE (SOP) PENYELESAIAN PERMOHONAN KEBERATAN DI KANTOR PELAYANAN PAJAK PRATAMA KENDARI
}

\author{
Randy Ariyadita Putra, SE.,M.Ak.,Ak.,CA ${ }^{(1)}$ \\ Rafida Bangki, SE.,M.Ak.,Ak ${ }^{(2)}$ \\ Fakultas Ekonomi \\ Universitas Nahdlatul Ulama Sulawesi Tenggara ${ }^{(1),(2)}$ \\ randyariyaditaputra@gmail.com \\ rafida_capri@yahoo.com
}

\begin{abstract}
Tax is one of the State revenue of the sources that were used to carry out national development activities. In increasing tax revenues, the government carried out reforms in the field of taxation which did not only occur at the organizational structure level, but also in terms of information systems and human resources including work procedures. One of them is determination of service standards relating to the processes of problem solving between the Director General of Taxes and taxpayers as in tax disputes. In the process of fulfilling tax obligations, the Self-Assessment principle on the implementation of the provisions of legislation applied to taxpayers creates a gap injustice. The Notice of Tax Assessment (SKP) issued causes the taxpayer to be dissatisfied with the provision so that a tax dispute arises.

At the Pratama Kendari Tax Service Office for the 2017 tax year process, the Standard Operating Procedure (SOP) is made based on the Minister of Finance Regulation Number PMK9/PMK.03/2013 concerning Procedures for Submitting and Resolving Objections and described in SE-11/PJ/2014 concerning Guidelines Implementation of Income Tax Objection Settlement, ValueAdded Tax and/or Sales Tax on Luxury Goods.

The study was conducted using a qualitative approach considering that what will be proven is the implementation of resolving objections to tax disputes between taxpayers and tax officials based on SOP.

The results of the study indicate that the implementation of the SOP for resolving objections has been in accordance with the Circular of the Directorate General of Taxes No. SE-11/PJ/2014 and Regulation of the Minister of Finance No. PMK-9/PMK.03/2013. SOP (Standard Operating Procedure) for resolving objections is also effective in the process of resolving objections at the Pratama Kendari Tax Service Office.

Keywords: tax, tax reform, Tax Disputes, Objections to tax, SOP.
\end{abstract}




\section{PENDAHULUAN}

\section{LATAR BELAKANG}

Indonesia adalah salah satu Negara yang sedang berkembang dalam melaksanakan kegiatan pembangunan yang bertujuan untuk meningkatkan kesejahteraan rakyat secara adil, makmur, merata, dapat dilihat melalui pembangunan nasional yang berlangsung secara berkesinanambungan dan tentunya tidak lepas dari masalah pembiayaan. Pemerintah harus mencari dana dengan memanfaatkan potensipotensi penerimaan Negara yang dapat digali, salah satu sumber penerimaan Negara yaitu pada sektor perpajakan.

Pajak mempunyai peranan yang sangat penting dalam kehidupan bernegara. Khususnya dalam pembangunan karena pajak merupakan sumber pendapatan Negara untuk membiayai semua pengeluaran yang harus dikeluarkan oleh Negara, termasuk salah satunya berupa pengeluaran pembangunan (Zuraida dan Advianto, 2011).

Undang-Undang Nomor 6 Tahun 1983 tentang Ketentuan Umum dan Tata Cara Perpajakan sebagaimana telah beberapa kali diubah terakhir dengan Undang-Undang Nomor 16 Tahun 2009, Pajak adalah kontribusi wajib kepada Negara yang terutang oleh orang pribadi atau badan yang bersifat memaksa berdasarkan Undang-Undang, dengan tidak mendapatkan imbalan secara langsung dan digunakan untuk keperluan Negara bagi sebesar-besarnya kemakmuran rakyat.

Sistem pemungutan pajak yang dianut oleh Indonesia adalah Self-Assessment System, yaitu wajib pajak diberi kepercayaan untuk menentukan sendiri besarnya pajak yang terutang dan diwajibkan untuk menghitung, membayar sendiri, dan melaporkan pajak yang terutang sesuai dengan ketentuan perundangundangan perpajakan melalui penyampaian Surat Pemberitahuan (Erly Suandy, 2011).

Dalam meningkatkan penerimaan pajak, pemerintah melakukan reformasi di bidang perpajakan yang tidak hanya terjadi di tingkat struktur organisasi, tetapi juga dalam hal sistem informasi dan sumber daya manusia termasuk prosedur kerja. Salah satunya yaitu penetapan standar pelayanan yang berhubungan dengan proses-proses penyelesaian masalah antara Dirjen Pajak dengan wajib pajak seperti pada sengketa pajak.

Penetapan standar pelayanan dapat mengatasi Vulnerability fraud (kerentanan kecurangan) pada suatu organisasi. Albrecht (2008) mengemukakan bahwa salah satu elemen yang berkontribusi dalam menciptakan lingkungan kerja yang positif, hingga mengurangi kerentanan organisasi terhadap kecurangan adalah memiliki personil prosedur operasional.

Dalam proses pemenuhan kewajiban pajak, prinsip Self-Assessment pada pelaksanaan ketentuan peraturan perundang-undangan yang diterapkan kepada wajib pajak menciptakan celah ketidakadilan. Surat Ketetapan Pajak (SKP) yang diterbitkan menyebabkan wajib pajak tidak puas atas ketetapan tersebut sehingga timbul sengketa pajak.

Penyelesaian sengketa atas ketidakpuasan hasil ketetapan pajak dimaksud, dimulai dengan wajib pajak mengajukan permohonan kepada instansi Dirjen Pajak melalui pengajuan keberatan untuk meninjau kembali keputusan tersebut.

Berbagai masalah yang timbul antara instansi perpajakan dengan wajib pajak terutama dalam menyelaraskan beban pajak yang harus dipikul oleh wajib pajak dengan pemenuhan kewajiban dan penggunaan hak di bidang perpajakan merupakan dampak dari upaya Dirjen Pajak untuk meningkatkan pendapatan pajak dan keadilan dalam hal perpajakan.

Berdasarkan latar belakang permasalahan di atas, maka dilakukan penelitian untuk mengetahui pelaksanaan Standard Operating Procedure (SOP) penyelesaian permohonan keberatan khususnya di Kantor Pelayanan Pajak (KPP) Pratama Kendari.

Penelitian ini dilakukan di Kota Kendari dengan mengambil fokus tahun 2017 untuk mendapatkan data/informasi terbaru (update) tentang wajib pajak yang mengajukan permohonan penyelesaian keberatan atas suatu ketetapan pajak.

Di Kantor Pelayanan Pajak Pratama Kendari, hasil rekapitulasi data penyelesaian permohonan keberatan terbaru yaitu pada tahun 
2017 (tahun pajak 2017) menunjukkan bahwa terdapat 12 (dua belas) permohonan keberatan. Permohonan keberatan tersebut diajukan oleh wajib pajak yang terdaftar di Kantor Pelayanan Pajak Pratama Kendari. Wajib pajak yang mengajukan permohonan keberatan adalah wajib pajak badan dan tak satu pun wajib pajak orang pribadi. Dari 12 (dua belas) permohonan keberatan diajukan oleh hanya 1 (satu) wajib pajak badan. 12 (dua belas) permohonan keberatan yang diajukan semuanya memenuhi persyaratan formal. Jangka waktu penyelesaian ke-12 (dua belas) permohonan keberatan yang diajukan adalah kurang dari 12 (dua belas) bulan. Hasil keputusan terhadap permohonan pengajuan keberatan dari wajib pajak yang mengajukan permohonan keberatan menunjukkan bahwa 5 (lima) permohonan dikabulkan sebagian dan 7 (tujuh) permohonan ditolak (KPP Pratama Kendari, 2017).

Berdasarkan latar belakang penelitian diatas, maka masalah dalam penelitian ini adalah apakah pelaksanaan penyelesaian permohonan keberatan di Kantor Pelayanan Pajak Pratama Kendari sesuai dengan SOP dan apakah SOP penyelesaian permohonan keberatan efektif dalam proses penyelesaian permohonan keberatan di Kantor Pelayanan Pajak Pratama Kendari.

Adapun tujuan dari penelitian ini yaitu untuk mengetahui pelaksanaan SOP penyelesaian permohonan keberatan di Kantor Pelayanan Pajak Pratama Kendari dan untuk mengetahui SOP penyelesaian permohonan keberatan efektif dalam proses penyelesaian permohonan keberatan di Kantor Pelayanan Pajak Pratama Kendari.

Sedangkan manfaat dari penelitian ini yaitu untuk memperoleh bukti pelaksanaan penyelesaian permohonan keberatan di Kantor Pelayanan Pajak Pratama Kendari sesuai dengan SOP dan untuk memperoleh bukti SOP penyelesaian permohonan keberatan efektif dalam proses penyelesaian permohonan keberatan di Kantor Pelayanan Pajak Pratama Kendari.

\section{KAJIAN PUSTAKA \\ Pengertian Pajak}

Menurut Undang-Undang Nomor 6 Tahun 1983 tentang Ketentuan Umum dan Tata
Cara Perpajakan sebagaimana telah beberapa kali diubah terakhir dengan Undang-Undang Nomor 16 Tahun 2009, pajak adalah "kontribusi wajib kepada negara yang terutang oleh orang pribadi atau badan yang bersifat memaksa berdasarkan Undang-Undang, dengan tidak mendapatkan imbalan secara langsung dan digunakan untuk keperluan Negara bagi sebesar-besarnya kemakmuran rakyat."

\section{Manfaat Pajak dan Fungsi Pajak Manfaat}

Suparmoko (2000) menyebutkan manfaat pajak digunakan untuk:

1) Manfaat pajak yang pertama adalah membiayai pengeluaran-pengeluaran Negara seperti pengeluaran yang bersifat self liquiditing (contohnya adalah pengeluaran untuk proyek produktif barang ekspor);

2) Manfaat pajak yang kedua adalah membiayai pengeluaran reproduktif (pengeluaran yang memberikan keuntungan ekonomis bagi masyarakat seperti pengeluaran untuk pengairan dan pertanian);

3) Manfaat pajak yang ketiga adalah membiayai pengeluaran yang bersifat tidak self liquiditing dan tidak reproduktif (contohnya adalah pengeluaran untuk pendirian monumen dan objek rekreasi);

4) Manfaat pajak yang keempat adalah membiayai pengeluaran yang tidak produktif (contohnya adalah pengeluaran untuk membiayai pertahanan Negara atau perang dan pengeluaran untuk penghematan di masa yang akan datang yaitu pengeluaran untuk anak yatim piatu).

\section{Fungsi}

Menurut Waluyo dan Wirawan B. Ilyas (1999) dalam Pramudijono (2009), terdapat beberapa fungsi pajak, yaitu:

1. Fungsi budgetair, yaitu fungsi untuk mengumpulkan uang pajak sebanyakbanyaknya sesuai undang-undang berlaku dan pada waktunya akan digunakan untuk membiayai pengeluaran-pengeluaran Negara; 
2. Fungsi regulerend, yaitu fungsi dimana pajak-pajak akan digunakan sebagai suatu alat untuk mencapai tujuan-tujuan tertentu yang letaknya di luar bidang keuangan. Dengan kata lain, pajak digunakan sebagai alat kebijaksanaan;

3. Fungsi demokrasi, yaitu fungsi yang merupakan salah satu wujud sistem gotong-royong, termasuk kegiatan pemerintah dan pembangunan demi kemaslahatan manusia;

4. Fungsi distribusi, yaitu fungsi yang lebih menekankan pada unsure pemerataan dan keadilan dalam masyarakat.

\section{Reformasi Perpajakan}

Anggito Abimayu (2004) menyebutkan bahwa "reformasi perpajakan adalah perubahan mendasar di segala aspek perpajakan yang memiliki tiga tujuan utama, yaitu tingkat kepatuhan suka rela yang tinggi, kepercayaan terhadap administrasi perpajakan yang tinggi, dan produktivitas terhadap aparat perpajakan yang tinggi."

\section{Pengertian Ketetapan Pajak}

Sengketa pajak timbul akibat adanya suatu ketetapan atau keputusan dari instansi Dirjen Pajak yang dirasa kurang adil oleh wajib pajak. Menurut Undang-Undang Nomor 14 Tahun 2002 tentang Pengadilan Pajak, Pasal 1 Ayat 4, ketetapan adalah "suatu penetapan tertulis di bidang perpajakan yang dikeluarkan oleh pejabat yang berwenang berdasarkan peraturan perundang-undangan perpajakan dan dalam rangka pelaksanaan Undang-undang Penagihan Pajak dengan Surat Paksa”.

Dalam Pasal 1 Ketentuan Umum dan Tata Cara Perpajakan (KUP), secara tegas memberikan istilah/batasan atas Ketetapan Pajak, yaitu:

1. Surat ketetapan pajak adalah surat ketetapan yang meliputi Surat Ketetapan Pajak Kurang Bayar, Surat Ketetapan Pajak Kurang Bayar Tambahan, Surat Ketetapan Pajak Nihil, atau Surat Ketetapan Pajak Lebih Bayar;

2. Surat Ketetapan Pajak Kurang Bayar adalah surat ketetapan pajak yang menentukan besarnya jumlah pokok pajak, jumlah kredit pajak, jumlah kekurangan pembayaran pokok pajak, besarnya sanksi administrasi, dan jumlah pajak yang masih harus dibayar;

3. Surat Ketetapan Pajak Kurang Bayar Tambahan adalah surat ketetapan pajak yang menentukan tambahan atas jumlah pajak yang telah ditetapkan;

4. Surat Ketetapan Pajak Nihil adalah surat ketetapan pajak yang menentukan jumlah pokok pajak sama besarnya dengan jumlah kredit pajak atau pajak tidak terutang dan tidak ada kredit pajak; Surat Ketetapan Pajak Lebih Bayar adalah surat ketetapan pajak yang menentukan jumlah kelebihan pembayaran pajak karena jumlah kredit pajak lebih besar daripada pajak yang terutang atau seharusnya tidak terutang.

\section{Keberatan Pajak}

Menurut Undang-Undang Ketentuan Umum dan Tata Cara Perpajakan (UU KUP), yang dimaksud Keberatan adalah "cara yang ditempuh oleh wajib pajak apabila wajib pajak merasa kurang atau tidak puas atas suatu ketetapan pajak yang dikenakan kepadanya atau pemotongan/pemungutan oleh pihak ketiga dalam pelakasanaan ketentuan peraturan perundang-undangan perpajakan”.

\section{Standard Operational Procedure (SOP) Definisi}

Menurut Atmoko (2006), standar operasional prosedur adalah pedoman atau acuan untuk melaksanakan tugas pekerjaan sesuai dengan fungsi dan alat penilaian kinerja instasi pemerintah berdasarkan indikator indikator teknis, administrasif dan prosedural sesuai dengan tata kerja, prosedur kerja dan sistem kerja pada unit kerja yang bersangkutan. Tujuan SOP adalah menciptakan komitmen mengenai apa yang dikerjakan oleh satuan unit kerja instansi pemerintahan untuk mewujudkan good governance.

\section{SOP Pengajuan Keberatan}

Dengan telah diterbitkannya Peraturan Menteri Keuangan Nomor 9/PMK.03/2013 tentang Tata Cara Pengajuan dan Penyelesaian Keberatan kemudian dijabarkan dalam Surat Edaran Direktur Jenderal Pajak Nomor SE-122/PJ/2010 tentang Pengantar Peraturan Direktur Jenderal Pajak Nomor PER52/PJ/2010 tentang Tata Cara Pengajuan dan Penyelesaian Keberatan Pajak Penghasilan, 
Pajak Pertambahan Nilai dan/atau Pajak Penjualan Atas Barang Mewah. Selanjutnya Surat Edaran ini dijadikan Standard Operating Procedure (SOP) sebagai acuan dalam rangka proses penyelesaian permohonan keberatan Wajib Pajak di lingkungan Kantor Pelayanan Pajak.

\section{Theory of Planned Behavior}

Menurut Theory of Planned Behavior, seseorang dapat bertindak berdasarkan intensi atau niatnya hanya jika ia memiliki kontrol terhadap perilakunya (Ajzen, 2002). Teori ini tidak hanya menekankan pada rasionalitas dari tingkah laku manusia, tetapi juga pada keyakinan bahwa target tingkah laku berada di bawah kontrol kesadaran individu tersebut atau suatu tingkah laku tidak hanya bergantung pada intensi seseorang, melainkan juga pada faktor lain yang tidak ada dibawah kontrol dari individu, misalnya ketersediaan sumber dan kesempatan untuk menampilkan tingkah laku tersebut (Ajzen, 2005).

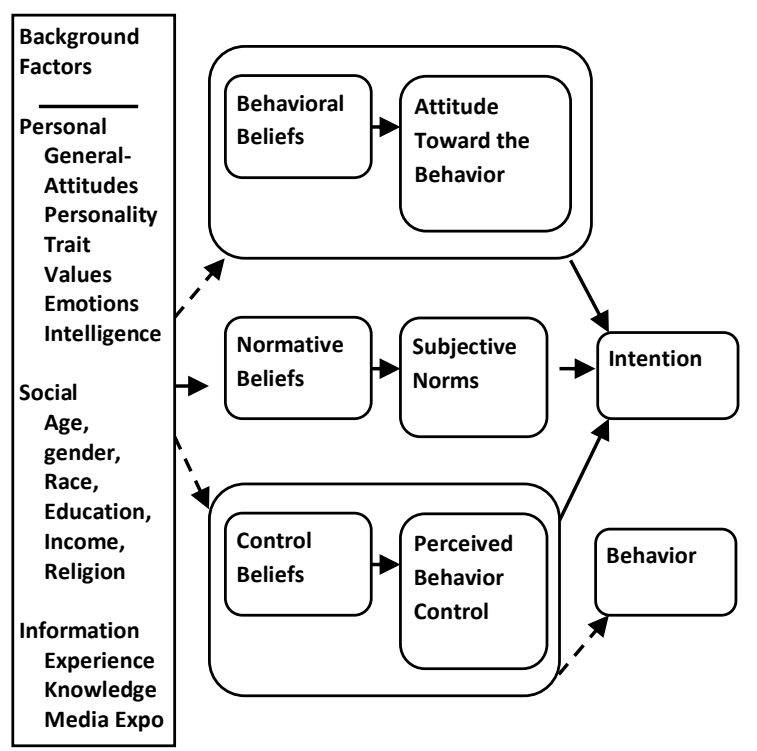

Gambar 1. Theory of Planned Behavior (Ajzen, 2005)

\section{Efektivitas}

Menurut Mahmudi (2010), efektivitas merupakan hubungan antara keluaran dengan tujuan atau sasaran yang harus dicapai. Dikatakan efektif apabila proses kegiatan mencapai tujuan dan sasaran akhir kebijakan (spending wisely). Semakin besar ouput yang dihasilkan terhadap pencapaian tujuan dan sasaran yang ditentukan, maka semakin efektif proses kerja suatu unit organisasi.

Efektivitas terkait penyelesaian pekerjaan tepat pada waktu yang telah ditetapkan sebelumnya atau dapat dikatakan apakah pelaksanaan sesuatu tercapai sesuai dengan yang direncanakan sebelumnya (Siagian, 2008).

Dari pendapat tentang efektivitas diatas terlihat bahwa efektivitas lebih menekankan pada aspek tujuan dari suatu organisasi, sehingga suatu organisasi dapat dikatakan telah mencapai efektifitas jika telah berhasil mencapai tujuan yang telah ditetapkan. Dengan kata lain bahwa efektifitas berorientasi pada pencapaian tujuan yang telah ditentukan sebelumnya.

\section{Telaah Pustaka}

Penelitian yang dilakukan oleh Fitria (2009) menyimpulkan bahwa pelaksanaan penyelesaian keberatan wajib pajak di Kantor Wilayah Direktorat Jenderal Pajak Daerah Istimewa Yogyakarta sudah berdasar dan sesuai dengan Surat Edaran Direktorat Jenderal Pajak Nomor SE-02/PJ.07/2007 Tentang Petunjuk Pelaksanaan Prosedur Penanganan Keberatan Pajak Penghasilan, Pajak Pertambahan Nilai dan Pajak Penjualan Atas Barang Mewah.

Penelitian yang dilakukan oleh Okta, Rendy Indrajaya \& Gustin Tanggulungan (2012) menunjukkan bahwa SOP Pendaftaran Perijinan dan Penyetoran Kas belum dipatuhi dan masuk dalam kategori cukup efektif, sedangkan SOP Penyerahan Perijinan berada dalam ketegori efektif.

Penelitian yang dilakukan oleh Putra (2015) menyimpulkan bahwa pelaksanaan SOP (Standard Operating Procedure) penyelesaian permohonan keberatan dan realisasinya telah sesuai dengan Surat Edaran Direktorat Jenderal Pajak nomor SE-122/PJ/2010 tentang Pengantar Peraturan Direktur Jenderal Pajak Nomor PER52/PJ/2010 tentang Tata Cara Pengajuan dan Penyelesaian Keberatan Pajak Penghasilan, Pajak Pertambahan Nilai dan/atau Pajak Penjualan Atas Barang Mewah dan Peraturan Menteri Keuangan nomor PMK9/PMK.03/2013 tentang Tata Cara Pengajuan dan Penyelesaian Keberatan.

\section{METODE PENELITIAN}




\section{Alasan Menggunakan Metode Kualitatif}

Penelitian kualitatif adalah penelitian yang menggunakan pendekatan naturalistik untuk mencari dan menemukan pengertian atau pemahaman tentang fenomena dalam suatu latar yang berkontek khusus. Penelitian kualitatif ini merupakan metode penelitian yang digunakan untuk meneliti pada kondisi objek yang alamiah dimana peneliti adalah sebagai instrument kunci.

Menurut Creswell (1998) dalam Emzir (2010) mengapa seseorang melakukan penelitian kualitatif, beberapa alasannya adalah karena hakikat pertanyaan penelitian dalam studi kualitatif dimulai dengan bagaimana dan apa. Dengan demikian, permulaan tersebut memaksa masuk ke dalam topik yang mendiskripsikan apa yang sedang berlangsung. Selain itu, memilih suatu studi kualitatif karena topik tersebut perlu dieksplorasi dan menyajikan sudut pandang yang mendetail tentang topik tersebut.

\section{Metode Penentuan Nara Sumber}

Penelitian kualitatif tidak menggunakan istilah populasi, tetapi oleh Spradley dinamakan "social situation" atau situasi sosial yang terdiri dari tiga elemen yaitu: tempat (place), pelaku (actors), dan aktivitas (activity) yang berinteraksi secara sinergis (Sugiyono, 2008). Sampling dalam penelitian kualitatif menurut Moleong (2005) adalah untuk menjaring sebanyak mungkin informasi dari berbagai macam sumber dan bangunannya. Tujuannya adalah untuk merinci kekhususan yang ada dalam ramuan konteks yang unik.

Sampel dalam penelitian kualitatif bukan dinamakan responden, tetapi sebagai nara sumber, atau partisipan, informan, teman, dan guru dalam penelitian. Pada penelitian kualitatif, peneliti memasuki situasi sosial tertentu, melakukan observasi dan wawancara kepada orang-orang yang dipandang tahu tentang situasi sosial tersebut (Sugiyono, 2014).

Sumber Data dan Teknik Pengumpulan Data

Menurut Lofland dan Lofland (1984) dalam Moleong (2005) sumber data utama dalam penelitian kualitatif ialah kata-kata dan tindakan, selebihnya adalah data tambahan seperti dokumen dan lain-lain. Sedangkan Emzir (2010) mengemukakan bahwa observasi, wawancara, dokumen pribadi, foto, rekaman, gambar dan percakapan informal merupakan sumber data kualitatif. Sumber data yang paling umum digunakan adalah observasi, wawancara dan dokumen.

Data sekunder yang digunakan oleh peneliti dalam penelitian ini adalah data sekunder internal, yaitu data dari KPP Pratama Kendari. Data-data tersebut berupa:

a. Peraturan Menteri Keuangan Nomor 9/PMK.03/2013 tentang Tata Cara Pengajuan dan Penyelesaian Keberatan.

b. Surat Edaran Direktur Jenderal Pajak Nomor SE-11/PJ/2014 tentang Petunjuk Pelaksanaan Penyelesaian Keberatan Pajak Penghasilan, Pajak Pertambahan Nilai Dan/Atau Pajak Penjualan Atas Barang Mewah.

c. Data statistik wajib pajak yang mengajukan keberatan pada tahun 2017.

Sedangkan data primer yang dilakukan dengan cara penelitian langsung di lapangan yaitu wawancara kepada pihak-pihak yang dipiih oleh peneliti yaitu:

a. Oky Cahya Kurniawan

Beliau adalah Kepala Seksi Pelayanan Kantor Pelayanan Pajak Pratama Kendari

b. Candra Dista

Beliau adalah bagian Seksi Pelayanan Kantor Pelayanan Pajak Pratama Kendari

c. Arianti

Beliau adalah bagian Tempat Pelayanan Terpadu Seksi Pelayanan Kantor Pelayanan Pajak Pratama Kendari

d. Eka

Beliau adalah bagian Tempat Pelayanan Terpadu Seksi Pelayanan Kantor Pelayanan Pajak Pratama Kendari

Selain data sekunder dan data primer di atas, peneliti juga menggunakan kuisioner yang didapatkan dari 6 (enam) orang di bagian Seksi Pelayanan Kantor Pelayanan Pajak Pratama Kendari.

\section{Instrumen Penelitian}

Dalam penelitian kualitatif, yang menjadi instrumen atau alat penelitian adalah peneliti itu sendiri (Sugiyono, 2009). Peneliti kualitatif sebagai human instrument, berfungsi menetapkan fokus, penelitian, memilih informan sebagai sumber data, melakukan pengumpulan 
data, menilai kualitas data, analisis data, menafsirkan data dan membuat kesimpulan atas temuannya.

Secara ringkas, Nasution (1988) dalam Sugiyono (2009) menyatakan bahwa dalam penelitian kualitatif tidak ada pilihan lain daripada menjadikan manusia sebagai instrumen penelitian utama. Alasannya, segala sesuatunya belum pasti. Segala sesuatu masih perlu dikembangkan dalam penelitian. Dalam keadaan serba tidak pasti dan tidak jelas, tidak ada pilihan lain dan hanya peneliti itu sendiri sebagai alat satu-satunya yang dapat mencapainya.

\section{Teknik Analisis Data}

Dalam penelitian ini analisis selama di lapangan menggunakan model Miles dan Huberman (Sugiyono, 2009). Miles dan Huberman mengemukakan bahwa aktivitas dalam analisis data kualitatif dilakukan secara interaktif dan berlangsung secara terus menerus sampai tuntas. Aktivitas dalam analisis data meliputi data reduction, data display, dan conclusion drawing/verification. Data reduction adalah aktivitas merangkum, memilih hal-hal yang pokok, memfokuskan pada hal-hal yang penting, dicari tema dan polanya. Data display adalah aktivitas penyajian data dalam bentuk uraian singkat, bagan, hubungan antar kategori, flowchart dan sejenisnya. Conclusion drawing adalah aktivitas penarikan kesimpulan dan verifikasi.

Pada praktek di lapangan peneliti melakukan pengambilan data dari Kantor Pelayanan Pajak Pratama Kendari yaitu SOP penyelesaian permohonan keberatan, diberikan kuisioner dan dilakukan wawancara.

\section{Pengujian Keabsahan Data Uji Kredibilitas}

Untuk mendapatkan data yang valid di dalam penelitian kualitatif ini, ukuran validitas suatu penelitian terdapat pada alat untuk menjaring data, apakah sudah tepat, benar, dan sesuai. Alat untuk menjaring data penelitian kualitatif terletak pada penelitian yang dibantu dengan metode wawancara dan observasi dan studi dokumen (Satori, 2009). Uji kredibilitas data atau kepercayaan terhadap data hasil penelitian kualitatif dilakukan dengan triangulasi, member check, dan menggunakan bahan referensi.

\section{Uji Transferability}

Transferability merupakan validitas eksternal dalam penelitian kuantitatif. Validitas eksternal menunjukkan derajat ketepatan. (Sugiyono, 2009). Agar orang lain dapat memahami hasil penelitian kualitatif, sehingga ada kemungkinan untuk menerapkan hasil penelitian tersebut, maka peneliti dalam membuat laporannya harus memberikan uraian yang rinci, jelas, sistematis dan dapat dipercaya. Bilamana pembaca laporan penelitian memperoleh gambaran yang sedemikian jelasnnya, maka suatu hasil penelitian dapat diberlakukan transferability, maka penelitian tersebut memenuhi standar transferabilitas. (Sanafiah dalam Sugiyono, 2009).

\section{HASIL DAN PEMBAHASAN}

Tata Cara Pengajuan dan Penyelesaian Keberatan di Direktorat Jenderal Pajak Peraturan Menteri Keuangan Nomor 9/PMK.03/2013 tentang Tata Cara Pengajuan dan Penyelesaian Keberatan Ketentuan Umum

Di dalam Bab I Ketentuan Umum Pasal

(1) Peraturan Menteri Keuangan Nomor 9/PMK.03/2013 tentang Tata Cara Pengajuan dan Penyelesaian Keberatan yang dimaksud Undang-Undang Nomor 6 Tahun 1983 tentang Ketentuan Umum dan Tata Cara Perpajakan sebagaimana telah beberapa kali diubah terakhir dengan Undang-Undang Nomor 16 Tahun 2009.

Di dalam Ketentuan Umum Pasal (1) juga menjelaskan yang dimaksud dengan Surat Keberatan adalah surat yang diajukan oleh Wajib Pajak kepada Direktur Jenderal Pajak mengenai keberatan terhadap suatu surat ketetapan pajak atau pemotongan atau pemungutan pajak oleh pihak ketiga.

\section{Ruang Lingkup}

Di dalam Bab II Ruang Lingkup Pasal (2) ayat (1) dijelaskan bahwa wajib pajak dapat mengajukan keberatan hanya kepada Direktur Jenderal Pajak atas suatu:

a. Surat Ketetapan Pajak Kurang Bayar;

b. Surat Ketetapan Pajak Kurang Bayar Tambahan;

c. Surat Ketetapan Pajak Lebih Bayar;

b. Surat Ketetapan Pajak Nihil; atau 
c. pemotongan atau pemungutan oleh pihak ketiga berdasarkan ketentuan

peraturan perundang-undangan perpajakan.

Pada Pasal (2) ayat (3) dijelaskan bahwa wajib pajak hanya dapat mengajukan keberatan sebagaimana dimaksud pada ayat (1) terhadap materi atau isi dari surat ketetapan pajak, yang meliputi jumlah rugi berdasarkan ketentuan peraturan perundang-undangan perpajakan, jumlah besarnya pajak, atau terhadap materi atau isi dari pemotongan atau pemungutan pajak. Sedangkan pada Pasal (2) ayat (5) dijelaskan bahwa keberatan sebagaimana dimaksud pada ayat (1) diajukan oleh wajib pajak dengan menyampaikan Surat Keberatan.

\section{Pengajuan Keberatan}

Di dalam Bab III Pengajuan Keberatan Pasal (3) ayat (1) dijelaskan bahwa pengajuan keberatan sebagaimana dimaksud dalam Pasal 2 ayat (1) untuk Tahun Pajak 2007 dan sebelumnya, harus memenuhi persyaratan sebagai berikut:

a. diajukan secara tertulis dalam bahasa Indonesia;

b. mengemukakan jumlah pajak yang terutang atau jumlah pajak yang dipotong atau dipungut atau jumlah rugi menurut penghitungan Wajib Pajak dengan disertai alasan-alasan yang menjadi dasar penghitungan;

c. 1 (satu) keberatan diajukan hanya untuk 1 (satu) surat ketetapan pajak, untuk 1 (satu) pemotongan pajak, atau untuk 1 (satu) pemungutan pajak;

d. diajukan dalam jangka waktu 3 (tiga) bulan sejak tanggal:

i. surat ketetapan pajak diterbitkan; atau

ii. pemotongan atau pemungutan pajak oleh pihak ketiga,

kecuali Wajib Pajak dapat menunjukan bahwa jangka waktu tersebut tidak dapat dipenuhi karena keadaan di luar kekuasaan Wajib Pajak;

e. Surat Keberatan ditandatangani oleh Wajib Pajak, dan dalam hal Surat Keberatan ditandatangani oleh bukan Wajib Pajak, Surat Keberatan tersebut harus dilampiri dengan surat kuasa khusus sebagaimana dimaksud dalam Pasal 32 ayat (3) Undang-Undang KUP; dan

f. Wajib Pajak tidak mengajukan permohonan sebagaimana dimaksud dalam Pasal 36 Undang-Undang KUP.

Di dalam Pasal (3) ayat (2) dijelaskan bahwa dalam hal Surat Keberatan yang disampaikan oleh wajib pajak tidak memenuhi persyaratan sebagaimana dimaksud pada ayat (1) huruf $a$, huruf $b$, huruf $c$, atau huruf e, Wajib Pajak dapat melakukan perbaikan atas Surat Keberatan tersebut dan menyampaikan kembali sebelum jangka waktu 3 (tiga) bulan sebagaimana dimaksud pada ayat (1) huruf $d$ terlampaui. Selanjutnya, pada Pasal (3) ayat (3) dijelaskan bahwa tanggal penyampaian Surat Keberatan yang telah diperbaiki sebagaimana dimaksud pada ayat (2) merupakan tanggal Surat Keberatan diterima.

Di dalam Pasal (4) ayat (1) dijelaskan bahwa pengajuan keberatan sebagaimana dimaksud dalam Pasal 2 ayat (1) untuk Tahun Pajak 2008 dan sesudahnya, harus memenuhi persyaratan sebagai berikut:

a. diajukan secara tertulis dalam bahasa Indonesia;

b. mengemukakan jumlah pajak yang terutang atau jumlah pajak yang dipotong atau dipungut atau jumlah rugi menurut penghitungan Wajib Pajak dengan disertai alasan-alasan yang menjadi dasar penghitungan;

c. 1 (satu) keberatan diajukan hanya untuk 1 (satu) surat ketetapan pajak, untuk 1 (satu) pemotongan pajak, atau untuk 1 (satu) pemungutan pajak;

d. Wajib Pajak telah melunasi pajak yang masih harus dibayar paling sedikit sejumlah yang telah disetujui Wajib Pajak dalam pembahasan akhir hasil pemeriksaan atau pembahasan akhir hasil verifikasi, sebelum Surat Keberatan disampaikan;

e. diajukan dalam jangka waktu 3 (tiga) bulan sejak tanggal:

1) surat ketetapan pajak dikirim; atau 
2) pemotongan atau pemungutan pajak oleh pihak ketiga,

kecuali Wajib Pajak dapat menunjukan bahwa jangka waktu tersebut tidak dapat dipenuhi karena keadaan di luar kekuasaan Wajib Pajak;

f. Surat Keberatan ditandatangani oleh Wajib Pajak, dan dalam hal Surat Keberatan ditandatangani oleh bukan Wajib Pajak, Surat Keberatan tersebut harus dilampiri dengan surat kuasa khusus sebagaimana dimaksud dalam Pasal 32 ayat (3) Undang-Undang KUP; dan

g. Wajib Pajak tidak mengajukan permohonan sebagaimana dimaksud dalam Pasal 36 Undang-Undang KUP.

Di dalam Pasal (4) ayat (2) dijelaskan bahwa dalam hal Surat Keberatan yang disampaikan oleh Wajib Pajak tidak memenuhi persyaratan sebagaimana dimaksud pada ayat (1) huruf a, huruf $b$, huruf $c$, huruf $d$, atau huruf f, Wajib Pajak dapat melakukan perbaikan atas Surat Keberatan tersebut dan menyampaikan kembali sebelum jangka waktu 3 (tiga) bulan sebagaimana dimaksud pada ayat (1) huruf e terlampaui. Dan pada Pasal (4) ayat (3) dijelaskan bahwa tanggal penyampaian Surat Keberatan yang telah diperbaiki sebagaimana dimaksud pada ayat (2) merupakan tanggal Surat Keberatan diterima.

Di dalam Pasal (5) ayat (1) dijelaskan bahwa keadaan di luar kekuasaan Wajib Pajak sebagaimana dimaksud dalam Pasal 3 ayat (1) huruf d dan Pasal 4 ayat (1) huruf e meliputi:

a. bencana alam;

b. kebakaran;

c. huru-hara/kerusuhan massal;

d. diterbitkan Surat Keputusan Pembetulan secara jabatan yang mengakibatkan jumlah pajak yang masih harus dibayar yang tertera dalam surat ketetapan pajak berubah, kecuali Surat Keputusan Pembetulan yang diterbitkan akibat hasil Persetujuan Bersama; atau

e. keadaan lain berdasarkan pertimbangan Direktur Jenderal Pajak.

Di dalam Pasal (6) dijelaskan bahwa dalam hal setelah Wajib Pajak mengajukan keberatan terdapat penerbitan Surat Keputusan Pembetulan oleh Direktur Jenderal Pajak secara jabatan yang mengakibatkan persyaratan jumlah pajak yang masih harus dilunasi sebagaimana dimaksud dalam Pasal 4 ayat (1) huruf d bertambah, proses penyelesaian keberatan yang diajukan oleh Wajib Pajak tersebut tetap dilanjutkan oleh Direktur Jenderal Pajak.

Di dalam Pasal (7) ayat (1) dijelaskan bahwa Surat Keberatan yang tidak memenuhi persyaratan sebagaimana dimaksud dalam Pasal 3 ayat (1) atau Pasal 4 ayat (1) tidak dipertimbangkan dan tidak diterbitkan Surat Keputusan Keberatan. Dan pada ayat (2) dijelaskan bahwa Surat Keberatan yang tidak memenuhi persyaratan dan tidak diterbitkan Surat Keputusan Keberatan sebagaimana dimaksud pada ayat (1) diberitahukan secara tertulis kepada Wajib Pajak melalui penyampaian surat pemberitahuan dengan menggunakan format sesuai contoh sebagaimana tercantum dalam Lampiran II yang merupakan bagian tidak terpisahkan dari Peraturan Menteri ini.

Di dalam Pasal (8) ayat (1) dijelaskan bahwa Surat pemberitahuan sebagaimana dimaksud dalam Pasal 7 ayat (2) bukan merupakan Surat Keputusan Keberatan sehingga tidak dapat diajukan banding ke badan peradilan pajak.

Di dalam Pasal (9) ayat (1) dijelaskan bahwa Wajib Pajak menyampaikan Surat Keberatan ke Kantor Pelayanan Pajak tempat Wajib Pajak terdaftar dan/atau tempat Pengusaha Kena Pajak dikukuhkan yang dapat dilakukan:

a. secara langsung;

b. melalui pos dengan bukti pengiriman surat; atau

c. dengan cara lain.

Di dalam Pasal (10) ayat (1) dijelaskan bahwa sebelum mengajukan keberatan, Wajib Pajak dapat meminta keterangan secara tertulis hal-hal yang menjadi dasar pengenaan pajak, penghitungan rugi, pemotongan atau pemungutan pajak kepada Direktur Jenderal Pajak melalui Kantor Pelayanan Pajak tempat Wajib Pajak terdaftar dan/atau tempat Pengusaha Kena Pajak dikukuhkan. Dan ayat (2) dijelaskan bahwa Direktur Jenderal Pajak wajib memberikan keterangan yang diminta oleh 
Wajib Pajak sebagaimana dimaksud pada ayat (1).

\section{Surat Edaran Direktur Jenderal Pajak Nomor SE-11/PJ/2014 tentang Petunjuk Pelaksanaan Penyelesaian Keberatan Pajak Penghasilan, Pajak Pertambahan Nilai Dan/Atau Pajak Penjualan Atas Barang Mewah}

Di dalam Surat Edaran Direktur Jenderal Pajak Nomor SE-11/PJ/2014 tentang Petunjuk Pelaksanaan Penyelesaian Keberatan Pajak Penghasilan, Pajak Pertambahan Nilai Dan/Atau Pajak Penjualan Atas Barang Mewah dijelaskan bagaimana Prosedur Penanganan Pengajuan Keberatan sebagai berikut:

1. Penerimaan Surat Keberatan

$$
\text { Petugas Tempat Pelayanan }
$$

Terpadu (TPT) pada Kantor Pelayanan Pajak (KPP) tempat Wajib Pajak terdaftar dan/atau tempat Pengusaha Kena Pajak dikukuhkan menerima Surat Keberatan Wajib Pajak yang disampaikan dengan cara:

a. secara langsung;

b. melalui pos dengan bukti pengiriman surat; atau

c. dengan cara lain meliputi

d. melalui perusahaan jasa ekspedisi atau jasa kurir dengan bukti pengiriman surat; atau e-Filing melalui Penyedia Jasa Aplikasi atau Application Service Provider (ASP).

Dalam hal Surat Keberatan disampaikan tidak melalui KPP tempat Wajib Pajak terdaftar dan/atau tempat Pengusaha Kena Pajak dikukuhkan, maka:

a. apabila Surat Keberatan disampaikan secara langsung di KPP selain KPP tempat Wajib Pajak terdaftar dan/atau tempat Pengusaha Kena Pajak dikukuhkan atau di Kantor Pelayanan Penyuluhan dan Konsultasi Perpajakan, petugas yang ditunjuk untuk menerima surat mengembalikan secara langsung Surat Keberatan tersebut kepada Wajib Pajak dan memberitahukan secara lisan tempat seharusnya Wajib Pajak menyampaikan Surat Keberatan; b. apabila Surat Keberatan disampaikan melalui pos atau cara lain di KPP selain KPP tempat Wajib Pajak terdaftar dan/atau tempat Pengusaha Kena Pajak dikukuhkan atau di Kantor Pelayanan Penyuluhan dan Konsultasi Perpajakan, unit kantor yang bersangkutan mengembalikan Surat Keberatan kepada Wajib Pajak dan memberitahukan secara tertulis tempat seharusnya Wajib Pajak menyampaikan Surat Keberatan;

c. apabila Surat Keberatan disampaikan di Kantor Wilayah Direktorat Jenderal Pajak atau Kantor Pusat Direktorat Jenderal Pajak, unit kantor yang bersangkutan mengembalikan Surat Keberatan kepada Wajib Pajak dan memberitahukan secara tertulis tempat seharusnya Wajib Pajak menyampaikan Surat Keberatan;

d. pengembalian Surat Keberatan sebagaimana dimaksud pada sub butir $b$ atau sub butir $\mathrm{c}$ dilakukan dengan menggunakan formulir sebagaimana contoh format pada Lampiran Surat Edaran ini;

e. pengembalian Surat Keberatan dilakukan paling lama:

a) 5 (lima) hari kerja setelah tanggal Surat Keberatan diterima di unit yang menerima surat, untuk Surat Keberatan sebagaimana dimaksud pada sub butir b; atau

b) 10 (sepuluh) hari kerja setelah tanggal Surat Keberatan diterima di unit yang menerima surat, untuk Surat Keberatan sebagaimana dimaksud pada sub butir c.

Petugas TPT membuat Lembar Pengawasan Arus Dokumen (LPAD) dan Bukti Penerimaan Surat (BPS) atas Surat Keberatan yang disampaikan Wajib Pajak dengan ketentuan sebagai berikut:

a. Penyampaian Surat Keberatan secara langsung.

Petugas TPT membuat bukti penerimaan surat berupa LPAD dan BPS dengan mengisi tanggal penerimaan surat sesuai tanggal diterimanya Surat Keberatan di TPT. Bukti penerimaan Surat Keberatan 
berupa LPAD dan BPS menjadi tanda bukti penerimaan Surat Keberatan.

b. Penyampaian Surat Keberatan melalui pos.

Petugas TPT membuat bukti penerimaan surat berupa LPAD dan BPS dengan mengisi tanggal penerimaan surat sesuai tanggal pengiriman pada bukti pengiriman Surat Keberatan melalui pos. Bukti pengiriman Surat Keberatan melalui pos menjadi tanda bukti penerimaan Surat Keberatan.

c. Penyampaian Surat Keberatan melalui perusahaan jasa ekspedisi atau jasa kurir. Petugas TPT membuat bukti penerimaan surat berupa LPAD dan BPS dengan mengisi tanggal penerimaan surat sesuai tanggal pengiriman pada bukti pengiriman Surat Keberatan melalui jasa ekspedisi atau jasa kurir. Bukti pengiriman Surat Keberatan melalui jasa ekspedisi atau jasa kurir menjadi tanda bukti penerimaan Surat Keberatan.

d. Penyampaian Surat Keberatan dengan cara e-Filing atau melalui Penyedia Jasa Aplikasi atau melalui Application Service Provider (ASP).

Petugas TPT membuat bukti penerimaan surat berupa LPAD dan BPS dengan mengisi tanggal penerimaan surat sesuai tanggal yang tercantum pada Bukti Penerimaan Elektronik. Bukti Penerimaan Elektronik pengiriman Surat Keberatan menjadi tanda bukti penerimaan Surat Keberatan.

Petugas TPT membuat Daftar Dokumen Lampiran Surat Keberatan dengan menggunakan formulir sebagaimana contoh format pada Lampiran Surat Edaran ini dan mengisi daftar tersebut sesuai dokumen yang dilampirkan dalam Surat Keberatan Wajib Pajak.

Daftar Dokumen Lampiran Surat Keberatan dibuat dalam rangkap 3 (tiga), dengan peruntukan sebagai berikut:

a. lembar ke-1 untuk Wajib Pajak;

b. lembar ke-2 untuk digabungkan dengan Surat Keberatan dan LPAD;

c. lembar ke-3 untuk arsip.
Petugas TPT mengirimkan LPAD, Surat Keberatan, dan Daftar Dokumen Lampiran Surat Keberatanke Seksi Pelayanan paling lama hari kerja berikutnya.

2. Penyiapan dan Pengiriman Berkas Keberatan

Seksi Pelayanan menerima LPAD, Surat Keberatan, dan Daftar Dokumen Lampiran Surat Keberatan dari Petugas TPT. Dalam hal terdapat gangguan pada Sistem Informasi Direktorat Jenderal Pajak, maka Seksi Pelayanan mengirimkan LPAD dan Surat Keberatan melalui faximili ke unit kantor Direktorat Jenderal Pajak yang berwenang untuk menerbitkan keputusan atas keberatan yang diajukan Wajib Pajak (selanjutnya disebut unit pelaksana penelitian keberatan), paling lama pada hari kerja berikutnya.

Seksi Pelayanan membuat Lembar Pengawasan Penelitian Berkas Keberatan dengan menggunakan formulir sebagaimana contoh format pada Lampiran Surat Edaran ini dan mencatat tahapan pelaksanaan kegiatan pada lembar tersebut.

Seksi Pelayanan menyiapkan berkas keberatan untuk dikirim ke unit pelaksana penelitian keberatan, yang meliputi:

a. Surat Keberatan Wajib Pajak;

b. dokumen yang dilampirkan dalam Surat Keberatan Wajib Pajak;

c. LPAD;

d. Bukti pengiriman Surat Keberatan melalui pos/jasa ekspedisi atau jasa kurir/Bukti Penerimaan Elektronik;

e. Daftar Dokumen Lampiran Surat Keberatan;

f. Lembar Pengawasan Penelitian Berkas Keberatan;

g. fotokopi surat ketetapan pajak dan bukti pengiriman surat ketetapan pajak;

h. fotokopi Berita Acara Pembahasan Akhir Hasil Pemeriksaan;

i. fotokopi Surat Setoran Pajak/bukti pemindahbukuan atau print out pembayaran pajak dari Modul 
Penerimaan Negara (dalam hal terdapat jumlah pajak yang masih harus dibayar paling sedikit sejumlah yang telah disetujui Wajib pajak dalam pembahasan akhir hasil pemeriksaan);

j. Lembar Isian Kelengkapan Berkas yang akan dikirimkan ke unit pelaksana penelitian keberatan.

Seksi Pelayanan mencatat kelengkapan berkas keberatan sebagaimana dimaksud pada berkas keberatan yang dikirim di atas dengan menggunakan formulir sebagaimana contoh format pada Lampiran Surat Edaran ini.

Seksi Pelayanan membuat surat pengantar untuk mengirim berkas keberatan dan meneruskan surat pengantar yang sudah ditandatangani Kepala KPP beserta berkas keberatan ke Sub Bagian Umum. Sub Bagian Umum mengirimkan surat pengantar beserta berkas keberatan sebagaimana dimaksud penjelasan diatas ke unit pelaksana penelitian keberatan. Penyiapan dan pengiriman berkas keberatan sebagaimana dimaksud di atas dilakukan paling lama 5 (lima) hari kerja setelah Surat Keberatan diterima.

3. Penyiapan dan Pengiriman Data, Informasi, dan/atau Dokumen

Seksi Pelayanan menerima dan mengadministrasikan surat permintaan data, informasi dan/atau dokumen dalam rangka penyelesaian keberatan dari unit pelaksana penelitian keberatan. Seksi Pelayanan mengirim data, informasi, dan/atau dokumen yang diminta ke unit pelaksana penelitian keberatan dengan menggunakan surat pengantar paling lama 5 (lima) hari kerja setelah surat permintaan diterima.

Dalam hal data, informasi, dan/atau dokumen yang diminta unit pelaksana penelitian keberatan berada di unit selain KPP tempat Wajib Pajak terdaftar dan/atau tempat Pengusaha Kena Pajak dikukuhkan, maka Seksi Pelayanan membuat surat permintaan data, informasi, dan/atau dokumen kepada unit lain tersebut dengan menggunakan formulir sebagaimana contoh format pada Lampiran Surat Edaran ini.

Surat permintaan sebagaimana dimaksud di atas dikirim paling lama 3 (tiga) hari kerja setelah surat permintaan data, informasi, dan/atau dokumen dari unit pelaksana penelitian keberatan diterima. Unit selain KPP tempat Wajib Pajak terdaftar dan/atau tempat Pengusaha Kena Pajak dikukuhkan mengirim data, informasi, dan/atau dokumen ke unit pelaksana penelitian keberatan paling lama 5 (lima) hari kerja setelah surat permintaan diterima.

4. Pemberian Keterangan secara Tertulis kepada Wajib Pajak untuk Keperluan Pengajuan keberatan

Seksi Pelayanan menerima dan mengadministrasikan surat permintaan keterangan secara tertulis dari Wajib Pajak mengenai hal-hal yang menjadi dasar pengenaan pajak, penghitungan rugi, pemotongan atau pemungutan pajak dalam surat ketetapan pajak atau bukti pemotongan atau pemungutan.

Seksi Pelayanan meneruskan surat permintaan keterangan sebagaimana dimaksud di atas paling lama hari kerja berikutnya ke:

a. Seksi Pemeriksaan dan Kepatuhan Internal, apabila permintaan keterangan dari Wajib Pajak terkait dengan surat ketetapan pajak hasil pemeriksaan; atau

b. Seksi Pengawasan dan Konsultasi, apabila permintaan keterangan dari Wajib Pajak terkait dengan surat ketetapan pajak hasil kegiatan verifikasi atau terkait dengan pemotongan atau pemungutan;

Seksi Pemeriksaan dan Kepatuhan Internal atau Seksi Pengawasan dan Konsultasi menyiapkan surat jawaban atas permintaan keterangan dan mengirimkan ke Wajib Pajak paling lama 15 (lima belas) hari kerja setelah tanggal surat permintaan keterangan diterima.

5. Permohonan Pencabutan Pengajuan Keberatan oleh Wajib Pajak

Petugas TPT di KPP tempat Wajib Pajak terdaftar dan/atau tempat Pengusaha Kena Pajak dikukuhkan 
menerima dan mengadministrasikan surat permohonan pencabutan pengajuan keberatan dari Wajib Pajak. Seksi Pelayanan meneruskan surat permohonan pencabutan pengajuan keberatan Wajib Pajak kepada unit pelaksana penelitian keberatan dengan surat pengantar yang dilampiri asli surat permohonan pencabutan pengajuan keberatan Wajib Pajak paling lama 3 (tiga) hari kerja setelah surat permohonan pencabutan pengajuan keberatan Wajib Pajak diterima.

Dalam hal surat permohonan pencabutan pengajuan keberatan disampaikan tidak melalui KPP tempat Wajib Pajak terdaftar dan/atau tempat Pengusaha Kena Pajak dikukuhkan, maka:

a. apabila surat permohonan pencabutan pengajuan keberatan disampaikan secara langsung di KPP selain KPP tempat Wajib Pajak terdaftar dan/atau tempat Pengusaha Kena Pajak dikukuhkan, atau di Kantor Pelayanan Penyuluhan dan Konsultasi Perpajakan, petugas yang ditunjuk untuk menerima surat mengembalikan secara langsung surat permohonan pencabutan pengajuan keberatan tersebut kepada Wajib Pajak dan memberitahukan secara lisan tempat seharusnya Wajib Pajak menyampaikan surat permohonan pencabutan pengajuan keberatan;

b. apabila surat permohonan pencabutan pengajuan keberatan disampaikan melalui pos atau cara lain di KPP selain KPP tempat Wajib Pajak terdaftar dan/atau tempat Pengusaha Kena Pajak dikukuhkan, atau di Kantor Pelayanan Penyuluhan dan Konsultasi Perpajakan, unit kantor yang bersangkutan mengembalikan surat permohonan pencabutan pengajuan keberatan kepada Wajib Pajak dan memberitahukan secara tertulis tempat seharusnya Wajib Pajak menyampaikan surat permohonan pencabutan pengajuan keberatan;

c. apabila surat permohonan pencabutan pengajuan keberatan disampaikan di Kantor Wilayah Direktorat Jenderal Pajak atau Kantor Pusat Direktorat Jenderal
Pajak, unit kantor yang bersangkutan mengembalikan surat permohonan pencabutan pengajuan keberatan kepada Wajib Pajak dan memberitahukan secara tertulis tempat seharusnya Wajib Pajak menyampaikan surat permohonan pencabutan pengajuan keberatan;

d. pengembalian surat permohonan pencabutan pengajuan keberatan sebagaimana dimaksud pada sub butir di atas dilakukan dengan menggunakan formulir sebagaimana contoh format pada Lampiran Surat Edaran ini dan disampaikan kepada Wajib Pajak paling lama 5 (lima) hari kerja setelah tanggal surat permohonan pencabutan pengajuan keberatan diterima di unit yang menerima surat.

6. Laporan

Seksi Pelayanan membuat Laporan Pengiriman Berkas Keberatan dan Non Keberatan dengan menggunakan formulir sebagaimana contoh format pada Lampiran Surat Edaran ini dan mengirimkan paling lambat tanggal 10 (sepuluh) bulan berikutnya kepada unit pelaksana penelitian keberatan. Seksi Pelayanan yang telah melaksanakan pengiriman laporan secara elektronik cukup mengirimkan laporan secara elektronik.

7. Lain-lain

Ilustrasi penghitungan jangka waktu

Wajib Pajak menyampaikan surat keberatan pada hari Senin, tanggal 4 November 2013 ke KPP Pratama A. Maka berdasarkan ketentuan sebagaimana diatur pada butir 2 diatas, penyiapan dan pengiriman berkas keberatan ke unit pelaksana penelitian keberatan dilakukan paling lama pada hari Senin tanggal 11 November 2013 (tanggal 9 dan tanggal 10 bukan hari kerja).

\section{Pelaksanaan SOP (Standard Operating Procedure) Penyelesaian Permohonan Keberatan di Kantor Pelayanan Pajak Pratama Kendari}

Menurut hasil wawancara dari Kepala Seksi Pelayanan Kantor Pelayanan Pajak 
Pratama Kendari Oky Cahya Kurniawan (Oky) menjelaskan bahwa wajib pajak berhak mengajukan keberatan jika tidak sependapat dengan Surat Ketetapan Pajak (SKP) yang diterbitkan oleh Dirjen Pajak. Pengajuan keberatan tersebut diatur dalam Undang-Undang Nomor 6 Tahun 1983 tentang Ketentuan Umum dan Tata Cara Perpajakan sebagaimana telah beberapa kali diubah terakhir dengan UndangUndang Nomor 16 Tahun 2009 pada penjelasan Pasal 25 ayat (1), apabila wajib pajak berpendapat bahwa jumlah rugi, jumlah pajak, dan pemotongan atau pemungutan pajak tidak sebagaimana mestinya, wajib pajak dapat mengajukan keberatan hanya kepada Direktur Jenderal Pajak (Putra, 2018).

Oky menjelaskan bahwa dalam hal pengajuan keberatan, proses diawali oleh wajib pajak mengirimkan berkas keberatan ke Kantor Pelayanan Pajak tempat wajib pajak terdaftar atau pengusaha kena pajak dikukuhkan. Kantor Pelayanan Pajak kemudian melakukan penelitian pemenuhan persyaratan Surat Keberatan dan jika Surat Keberatan memenuhi persyaratan formal selanjutnya mengirimkan ke Unit Pelaksana Penelitian Keberatan di Kantor Wilayah Direktorat Jenderal Pajak. Oky menjelaskan bahwa Kantor Pelayanan Pajak Pratama Kendari sebagai tempat menerima dan meneliti kelengkapan berkas keberatan sesuai persyaratan dari wajib pajak. Sedangkan untuk proses penyelesaian permohonan keberatan diselesaikan di Kantor Wilayah, untuk Kota Kendari termasuk di dalam Kantor Wilayah Direktorat Jenderal Pajak Sulawesi Selatan, Barat, dan Tenggara (Putra, 2018).

Selanjutnya Oky menyatakan bahwa adapun Standard Operating Procedure (SOP) penyelesaian permohonan keberatan di Kantor Pelayanan Pajak Pratama Kendari untuk tahun 2017 dibuat dan disusun berdasarkan Surat Edaran Direktorat Jenderal Pajak nomor SE11/PJ/2014 tentang Petunjuk Pelaksanaan Penyelesaian Keberatan $\mathrm{PPh}$, PPN dan/atau PPnBM yang didasari atas Peraturan Menteri Keuangan nomor PMK-9/PMK.03/2013 tentang Tata Cara Pengajuan dan Penyelesaian Keberatan (Putra, 2018).

Menurut hasil wawancara dari Kepala Seksi Pelayanan Kantor Pelayanan Pajak
Pratama Kendari Oky menjelaskan bahwa SOP tersebut bertujuan untuk mendorong tertib administrasi penyelesaian keberatan Pajak Penghasilan, Pajak Pertambahan Nilai dan/atau Pajak Penjualan atas Barang Mewah, sehingga keberatan wajib pajak diselesaikan sesuai batas waktu penyelesaian sebagaimana ditetapkan dalam Undang-Undang Ketentuan Umum dan Tata Cara Perpajakan. Selain itu dimaksudkan agar wajib pajak dan pegawai pajak yang berwenang tidak sendiri-sendiri menentukan terkait jangka waktu pelaksanaan, format surat, dan sebagainya (Putra, 2018).

Mengenai atas keberatan pajak apa saja SOP tersebut berlaku, Oky kemudian menjelaskan bahwa sesuai dengan Bab II mengenai Ruang Lingkup Pasal 2 ayat (1) Peraturan Menteri Keuangan nomor PMK9/PMK.03/2013 menyebutkan bahwa wajib pajak dapat mengajukan keberatan hanya kepada Direktur Jenderal Pajak atas suatu (Putra, 2018):

a. Surat Ketetapan Pajak Kurang Bayar;

b. Surat Ketetapan Pajak Kurang Bayar Tambahan;

c. Surat Ketetapan Pajak Lebih Bayar;

d. Surat Ketetapan Pajak Nihil; atau

e. Pemotongan atau pemungutan oleh pihak ketiga berdasarkan ketentuan peraturan perundang-undangan perpajakan.

Sedangkan terkait berapa lama jangka waktu penyelesaian permohonan keberatan di Kantor Pelayanan Pajak Pratama Kendari Oky selanjutnya menjelaskan bahwa sebagaimana dijelaskan sebelumnya bahwa Kantor Pelayanan Pajak Pratama Kendari hanya sebagai tempat menerima dan meneliti kelengkapan berkas keberatan sedangkan untuk proses penyelesaian permohonan keberatan diselesaikan di Kantor Wilayah maka jangka waktu penyiapan hingga pengiriman berkas keberatan dilakukan paling lama 5 (lima) hari kerja setelah Surat Keberatan diterima (Putra, 2018).

Mengenai apakah pelaksanaan SOP di Kantor Pelayanan Pajak Pratama Kendari sesuai dengan tata urutan yang ada dalam aturan yang berlaku, menurut hasil wawancara dari Oky menjelaskan bahwa pelaksanaan SOP penyelesaian permohonan keberatan di Kantor Pelayanan Pajak Pratama Kendari mengikuti tata urutan pelaksanaan sesuai dengan peraturan 
yang tertulis dalam Surat Edaran Nomor SE11/PJ/2014 tentang Petunjuk Pelaksanaan Penyelesaian Keberatan Pajak Penghasilan, Pajak Pertambahan Nilai dan/atau Pajak Penjualan Atas barang Mewah mengikuti alur prosedur (Putra, 2018).

Kemudian, Oky berpendapat bahwa tata urutan pelaksanaan SOP penyelesaian permohonan keberatan di Kantor Pelayanan Pajak Pratama Kendari adalah sama untuk semua wajib pajak tidak terkecualikan. Prosesnya pun sama satu sama lain konsisten sesuai dengan SOP yang berlaku (Putra, 2018).

Selanjutnya, Oky berpendapat bahwa Direktorat Jenderal Pajak merupakan salah satu instansi yang sangat ketat dan tertib dalam hal pelaksanaan SOP diantara instansi lain. Sehingga Oky dapat mengambil kesimpulan bahwa pelaksanaan SOP penyelesaian permohonan keberatan di Kantor Pelayanan Pajak Pratama Kendari dilaksanakan sesuai dengan SOP yang berlaku (Putra, 2018).

Menurut hasil wawancara dari Seksi Pelayanan Kantor Pelayanan Pajak Pratama Kendari Candra Dista (Candra) menyatakan bahwa tidak ada biaya dalam proses penyelesaian permohonan pengajuan keberatan di Kantor Pelayanan Pajak Pratama Kendari. SOP penyelesaian permohonan keberatan di Kantor Pelayanan Pajak Pratama Kendari disusun berdasarkan Surat Edaran Direktorat Jenderal Pajak nomor SE-11/PJ/2014 tentang Petunjuk Pelaksanaan Penyelesaian Keberatan Pajak Penghasilan, Pajak Pertambahan Nilai dan/atau Pajak Penjualan Atas barang Mewah dimana di dalam SOP tersebut tidak menyebutkan adanya biaya yang harus dikeluarkan dalam proses dari awal dimana wajib pajak pertama kali menyampaikan Surat Keberatan hingga akhir dimana wajib pajak menerima Keputusan Surat Keberatan (Putra, 2018).

Menurut hasil wawancara dari bagian Tempat Pelayanan Terpadu Seksi Pelayanan Kantor Pelayanan Pajak Pratama Kendari Arianti menjelaskan bahwa prosedur awal penyelesaian permohonan keberatan dimulai dengan menerima Surat Keberatan dari wajib pajak. Pelaksanaannya mengacu pada SOP yang berlaku di Kantor Pelayanan Pajak Pratama
Kendari, yaitu SOP penyelesaian permohonan keberatan. Adapun mengenai apakah pelaksanaan SOP di Kantor Pelayanan Pajak Pratama Kendari sesuai dengan tata urutan yang ada dalam aturan yang berlaku, Arianti menjelaskan bahwa pelaksanaan SOP penyelesaian permohonan keberatan di Kantor Pelayanan Pajak Pratama Kendari mengikuti tata urutan pelaksanaan sesuai dengan SOP yang berlaku. Selanjutnya Arianti menjelaskan bahwa setiap Surat Keberatan yang diajukan oleh wajib pajak tata urutan pelaksanaan SOP-nya sama satu sama lain tidak ada perbedaan antara satu wajib pajak dengan wajib pajak yang lain (Putra, 2018).

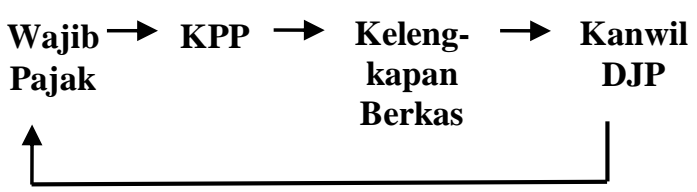

Gambar 2. Skema Penyelesaian Permohonan Keberatan di Kantor Pelayanan Pajak Pratama Kendari

\section{Sumber: KPP Pratama Kendari}

Dari hasil wawancara dengan Seksi Pelayanan Kantor Pelayanan Pajak Pratama Kendari Oky dan Candra, dan bagian Tempat Pelayanan Terpadu Seksi Pelayanan Kantor Pelayanan Pajak Pratama Kendari Arianti dapat dilihat bahwa pelaksanaan SOP penyelesaian permohonan keberatan di Kantor Pelayanan Pajak Pratama Kendari telah sesuai dengan SOP yang berlaku berdasarkan Surat Edaran Direktorat Jenderal Pajak nomor SE-11/PJ/2014 tentang Petunjuk Pelaksanaan Penyelesaian Keberatan Pajak Penghasilan, Pajak Pertambahan Nilai dan/atau Pajak Penjualan Atas barang Mewah. Hal ini dibuktikan dengan hasil kuisioner dari bagian Seksi Pelayanan Kantor Pelayanan Pajak Pratama Kendari yang menyatakan bahwa pelaksanaan SOP sesuai dengan SOP penyelesaian permohonan keberatan yang berlaku.

Menurut Theory of Planned Behavior, dari hasil wawancara dari Seksi Pelayanan Kantor Pelayanan Pajak Pratama Kendari Oky 
dan Candra, dan bagian Tempat Pelayanan Terpadu Seksi Pelayanan Kantor Pelayanan Pajak Pratama Kendari Arianti, seseorang dapat bertindak berdasarkan intensi atau niatnya hanya jika ia memiliki kontrol terhadap perilakunya (Ajzen, 2002). Dapat diartikan bahwa pelaksanaan SOP penyelesaian keberatan di Kantor Pelayanan Pajak Pratama Kendari tergantung dari niat para pelaksana yang terkait atau yang terlibat dalam proses penyelesaian keberatan sehingga SOP terlaksana sesuai dengan peraturan yang telah ditetapkan oleh Dirjen Pajak dalam Surat Edaran Direktorat Jenderal Pajak nomor SE-11/PJ/2014 dan Peraturan Menteri Keuangan nomor PMK9/PMK.03/2013.

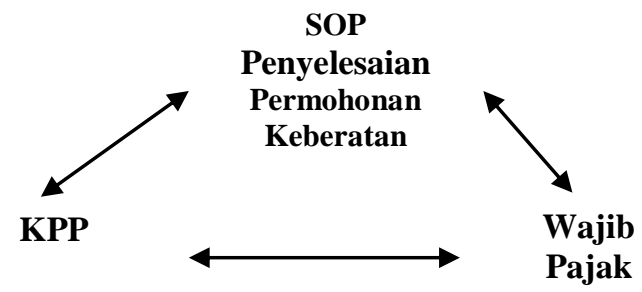

Gambar 3. Skema Triangulasi

\section{SOP (Standard Operating Procedure) Penyelesaian Permohonan Keberatan Efektif Dalam Proses Penyelesaian Permohonan Keberatan di KPP Pratama Kendari.}

Menurut hasil wawancara dengan

Candra bagian Seksi Pelayanan Kantor Pelayanan Pajak Pratama Kendari menjelaskan bahwa wajib pajak apabila tidak sependapat dengan Surat Ketetapan Pajak (SKP) yang diterbitkan oleh Dirjen Pajak berhak mengajukan keberatan sesuai dengan UndangUndang Nomor 6 Tahun 1983 tentang Ketentuan Umum dan Tata Cara Perpajakan sebagaimana telah beberapa kali diubah terakhir dengan Undang-Undang Nomor 16 Tahun 2009 (Putra, 2018).

Di Kantor Pelayanan Pajak Pratama Kendari, hasil rekapitulasi data penyelesaian permohonan keberatan terbaru yaitu pada tahun 2017 (tahun pajak 2017) menunjukkan bahwa terdapat 12 (dua belas) permohonan keberatan. Permohonan keberatan tersebut diajukan oleh wajib pajak yang terdaftar di Kantor Pelayanan Pajak Pratama Kendari. Wajib pajak yang mengajukan permohonan keberatan adalah wajib pajak badan dan tak satu pun wajib pajak orang pribadi. Dari 12 (dua belas) permohonan keberatan diajukan oleh hanya 1 (satu) wajib pajak badan. 12 (dua belas) permohonan keberatan yang diajukan semuanya memenuhi persyaratan formal. Jangka waktu penyelesaian ke-12 (dua belas) permohonan keberatan yang diajukan adalah kurang dari 12 (dua belas) bulan. Hasil keputusan terhadap permohonan pengajuan keberatan dari wajib pajak yang mengajukan permohonan keberatan menunjukkan bahwa 5 (lima) permohonan dikabulkan sebagian dan 7 (tujuh) permohonan ditolak (KPP Pratama Kendari, 2017).

Candra menjelaskan bahwa untuk permohonan keberatan pada tahun pajak 2017 SOP penyelesaian permohonan keberatan yang berlaku di Kantor Pelayanan Pajak Pratama Kendari dibuat dan disusun berdasarkan Surat Edaran Direktorat Jenderal Pajak nomor SE11/PJ/2014 tentang Petunjuk Pelaksanaan Penyelesaian Keberatan PPh, PPN dan/atau PPnBM yang didasari atas Peraturan Menteri Keuangan nomor PMK-9/PMK.03/2013 tentang Tata Cara Pengajuan dan Penyelesaian Keberatan (Putra, 2018).

Kemudian Candra menjelaskan bahwa proses penyelesaian permohonan keberatan dimulai oleh wajib pajak mengirimkan berkas keberatan ke Kantor Pelayanan Pajak dengan cara datang langsung atau melalui kantor POS atau jasa pengiriman dimana tempat wajib pajak terdaftar melalui Tempat Pelayanan Terpadu di Kantor Pelayanan Pajak. Kantor Pelayanan Pajak kemudian hanya melakukan penelitian pemenuhan persyaratan Surat Keberatan dan selanjutnya mengirimkan ke Unit Pelaksana Penelitian Keberatan di Kantor Wilayah Direktorat Jenderal Pajak (Putra, 2018).

Selanjutnya Candra menjelaskan bahwa jangka waktu penyelesaian permohonan keberatan pada tahun pajak 2017 di Kantor Pelayanan Pajak Pratama Kendari diselesaikan dalam 5 (lima) hari kerja dari Surat Keberatan diterima hingga pengiriman berkas keberatan ke Kantor Wilayah. Mengenai apakah pelaksanaan SOP di Kantor Pelayanan Pajak Pratama Kendari sesuai dengan tata urutan yang ada dalam aturan yang berlaku, Candra menjelaskan 
bahwa pelaksanaan SOP penyelesaian permohonan keberatan di Kantor Pelayanan Pajak Pratama Kendari mengikuti tata urutan alur prosedur pelaksanaan sesuai dengan peraturan yang tertulis dalam Surat Edaran Nomor SE-11/PJ/2014 tentang Petunjuk Pelaksanaan Penyelesaian Keberatan Pajak Penghasilan, Pajak Pertambahan Nilai dan/atau Pajak Penjualan Atas barang Mewah (Putra, 2018).

Menurut hasil wawancara dengan Candra tidak dapat menjelaskan atas keberatan apa saja terkait permohonan keberatan dari wajib pajak yang mengajukan permohonan keberatan pada tahun 2017 tersebut. Hal ini dikarenakan aturan dari Kantor Pelayanan Pajak Pratama Kendari untuk mengajukan surat resmi kepada Kepala Kantor Wilayah untuk mendapatkan data lengkap terkait wajib pajak yang mengajukan keberatan di lingkungan Kantor Pelayanan Pajak Pratama Kendari (Putra, 2018).

Menurut hasil wawancara dari bagian Tempat Pelayanan Terpadu Seksi Pelayanan Kantor Pelayanan Pajak Pratama Kendari Eka menjelaskan bahwa untuk tahun pajak 2017 permohonan keberatan dimulai dengan menerima Surat Keberatan dari wajib pajak melalui loket Tempat Pelayanan Terpadu Kantor Pelayanan Pajak Pratama Kendari secara langsung. Permohonan keberatan yang diterima di loket Tempat Pelayanan Terpadu kemudian dilakukan pemeriksaan kelengkapan berkas wajib pajak pemohon. Berkas keberatan dianggap lengkap kemudian diterima (Putra, 2018).

Kemudian Eka menjelaskan bahwa pelaksanaan SOP di Kantor Pelayanan Pajak Pratama Kendari sesuai dengan tata urutan yang ada dalam aturan yang berlaku. Setelah menerima berkas keberatan dari wajib pajak kemudian membuat Lembar Pengawasan Arus Dokumen dan Bukti Penerimaan Surat. Kemudian membuat Daftar Dokumen Lampiran Surat Keberatan. Selanjutnya mengirimkan Lembar Pengawasan Arus Dokumen, Bukti Penerimaan Surat, dan Daftar Dokumen Lampiran Surat Keberatan ke Seksi Pelayanan. Bagian Seksi Pelayanan kemudian menyiapkan berkas keberatan dan mengirim berkas keberatan tersebut ke Unit Pelaksana Penelitian Keberatan di Kantor Wilayah (Putra, 2018).

Selanjutnya Eka menjelaskan bahwa dalam proses penyelesaian permohonan keberatan untuk tahun pajak 2017 tidak terdapat keluhan dari wajib pajak atas pelaksanaan permohonan keberatan yang diajukan. Berikutnya Eka menjelaskan bahwa tidak terdapat kendala dalam proses penyelesaian pelaksanaan SOP penyelesaian permohonan keberatan di Kantor Pelayanan Pajak Pratama Kendari baik yang dihadapi oleh bagian pelayanan, terutama bagian Tempat Pelayanan Terpadu, maupun oleh wajib pajak yang mengajukan keberatan. Wajib pajak memberikan berkas keberatan kepada bagian Tempat Pelayanan Terpadu dengan berkas yang lengkap sehingga dapat diterima (Putra, 2018).

Menurut hasil wawancara dari bagian Tempat Pelayanan Terpadu Seksi Pelayanan Kantor Pelayanan Pajak Pratama Kendari Eka menjelaskan bahwa tidak ada biaya dalam proses penyelesaian permohonan pengajuan keberatan di Kantor Pelayanan Pajak Pratama Kendari. Hal tersebut sesuai dengan SOP penyelesaian permohonan keberatan yang berlaku dan diterapkan oleh Kantor Pelayanan Pajak Pratama Kendari (Putra, 2018).

Menurut hasil wawancara dari bagian Seksi Pelayanan Kantor Pelayanan Pajak Pratama Kendari Candra menyatakan bahwa SOP penyelesaian permohonan keberatan efektif dalam proses penyelesaian permohonan keberatan di Kantor Pelayanan Pajak Pratama Kendari. Candra menjelaskan bahwa dalam pelaksanaan proses penyelesaian permohonan keberatan dilaksanakan sesuai dengan alur prosedur yang tertuang dalam SOP yang disusun berdasarkan Surat Edaran Direktorat Jenderal Pajak nomor SE-11/PJ/2014 tentang Petunjuk Pelaksanaan Penyelesaian Keberatan PPh, PPN dan/atau PPnBM yang didasari atas Peraturan Menteri Keuangan nomor PMK9/PMK.03/2013 tentang Tata Cara Pengajuan dan Penyelesaian Keberatan (Putra, 2018).

Menurut hasil wawancara dari bagian Tempat Pelayanan Terpadu Seksi Pelayanan Kantor Pelayanan Pajak Pratama Kendari Eka menjelaskan hal yang sama dengan Candra bahwa SOP penyelesaian permohonan keberatan 
efektif dalam proses penyelesaian permohonan keberatan di Kantor Pelayanan Pajak Pratama Kendari. Hal ini dibuktikan dalam proses penyelesaian permohonan keberatan yang diajukan oleh wajib pajak badan yang mengajukan Surat Keberatan pada tahun pajak 2017 yang telah diproses oleh Kantor Pelayanan Pajak Pratama Kendari. Dimana prosesnya sesuai dengan alur prosedur yang tertuang SOP yang berlaku (Putra, 2018).

Dari hasil wawancara dengan Seksi Pelayanan Kantor Pelayanan Pajak Pratama Kendari Candra dan bagian Tempat Pelayanan Terpadu Seksi Pelayanan Kantor Pelayanan Pajak Pratama Kendari Eka dapat dilihat bahwa pelaksanaan SOP penyelesaian permohonan keberatan efektif dalam proses penyelesaian permohonan keberatan di Kantor Pelayanan Pajak Pratama Kendari karena dilaksanakan sesuai dengan alur prosedur SOP yang berlaku berdasarkan Surat Edaran Direktorat Jenderal Pajak nomor SE-11/PJ/2014 tentang Petunjuk Pelaksanaan Penyelesaian Keberatan Pajak Penghasilan, Pajak Pertambahan Nilai dan/atau Pajak Penjualan Atas barang Mewah.

Mahmudi (2010) menyatakan bahwa efektivitas merupakan hubungan antara keluaran dengan tujuan atau sasaran yang harus dicapai. Dikatakan efektif apabila proses kegiatan mencapai tujuan dan sasaran akhir kebijakan (spending wisely). Sedangkan Siagian (2008) berpendapat bahwa efektivitas terkait penyelesaian pekerjaan tepat pada waktu yang telah ditetapkan sebelumnya atau dapat dikatakan apakah pelaksanaan sesuatu tercapai sesuai dengan yang direncanakan sebelumnya. Dari hasil wawancara dengan Seksi Pelayanan Kantor Pelayanan Pajak Pratama Kendari Candra dan bagian Tempat Pelayanan Terpadu Seksi Pelayanan Kantor Pelayanan Pajak Pratama Kendari Eka dapat dilihat bahwa proses kegiatan mencapai tujuan dan sasaran akhir kebijakan (spending wisely), dimana tujuan dari SOP permohonan penyelesaian keberatan yaitu mendorong tertib administrasi, berkas keberatan yang dibutuhkan oleh Dirjen Pajak terpenuhi oleh wajib pajak sesuai dengan SOP yang berlaku bahwa wajib pajak harus melengkapi berkas keberatan untuk dapat diteliti dan dikabulkan permohonannya. Kemudian terkait penyelesaian pekerjaan tepat pada waktu yang telah ditetapkan sebelumnya, dapat dilihat bahwa proses penyelesaian permohonan keberatan di Kantor Pelayanan Pajak Pratama Kendari untuk tahun pajak 2017 diselesaikan tepat waktu, yaitu 5 (lima) hari kerja setelah Surat Keberatan diterima oleh petugas di loket Tempat Pelyanan Terpadu Kantor Pelayanan Pajak Pratama Kendari.

Menurut hasil wawancara dengan Seksi Pelayanan Kantor Pelayanan Pajak Pratama Kendari Candra dan bagian Tempat Pelayanan Terpadu Seksi Pelayanan Kantor Pelayanan Pajak Pratama Kendari Eka dengan teori efektifitas dapat disimpulkan bahwa SOP (Standard Operating Procedure) penyelesaian permohonan keberatan efektif dalam proses penyelesaian permohonan keberatan di Kantor Pelayanan Pajak Pratama Kendari.

\section{KESIMPULAN DAN SARAN}

\section{Kesimpulan}

Berdasarkan hasil analisis data seperti yang telah diuraikan dalam Bab Analisis Data dan Pembahasan, maka dapat ditarik kesimpulan sebagai berikut:

1. Hasil penelitian ini menunjukkan bahwa pelaksanaan SOP (Standard Operating Procedure) penyelesaian permohonan keberatan telah sesuai dengan Surat Edaran Direktorat Jenderal Pajak nomor SE-11/PJ/2014 tentang tentang Petunjuk Pelaksanaan Penyelesaian Keberatan $\mathrm{PPh}, \mathrm{PPN}$ dan/atau PPnBM yang didasari atas Peraturan Menteri Keuangan nomor PMK-9/PMK.03/2013 tentang Tata Cara Pengajuan dan Penyelesaian Keberatan.

2. Hasil penelitian ini menunjukkan bahwa SOP penyelesaian permohonan keberatan efektif dalam proses penyelesaian permohonan keberatan di Kantor Pelayanan Pajak Pratama Kendari.

\section{Keterbatasan Penelitian}

Penelitian ini memiliki beberapa keterbatasan dalam hal pengumpulan data antara lain:

1. Penelitian yang menggunakan metode uji kredibilitas dimana pada aspek 
triangulasi sumber dalam mengecek data dari beberapa pihak narasumber sangat sulit, dikarenakan ada beberapa narasumber tidak bisa memberikan keterangannya.

2. Peneliti sulit mendapat data langsung dari wajib pajak yang mengajukan keberatan pada tahun 2017 karena proses birokrasi yang ketat dari Direktorat Jenderal Pajak, tidak semua informasi diberikan karena adanya rahasia jabatan yang diatur oleh Undang-Undang.

3. Penelitian dilakukan hanya untuk mengevaluasi pelaksanaan SOP.

\section{Saran}

Beberapa saran yang ingin disampaikan peneliti untuk kedepannya antara lain:

1. Untuk yang terkait dengan pelaksanaan SOP penyelesaian permohonan keberatan sebaiknya wajib pajak memahami terlebih dahulu bagaimana prosedur pengajuan keberatan yang ada di Direktorat Jenderal Pajak sebelum mengajukan keberatan.

2. Bagi peneiti selanjutnya, sebelum masuk ke SOP sebaiknya mencari dan menganalisa kasus sengketa pajak yang dihadapi oleh wajib pajak terlebih dahulu sehingga adanya batasan penelitian dan penelitian menjadi lebih spesifik.

\section{DAFTAR PUSTAKA}

Abimayu, Anggito. 2004. Exit Strategy Dan Kemandirian Kebijakan Fiscal Indonesia Dalam Kebijakan Fiscal Pemikiran, Konsep, Dan Implementasi. Jakarta: Kompas.

Ajzen, Icek. 2002. Constructing a TPB Questionnaire: Conceptual and Methodological Considerations. http://www.unibielefeld.de/ikg/zick/ajze $\mathrm{n} \% 20$ construction $\% 20 \mathrm{a} \% 20 \mathrm{tpb} \% 20 \mathrm{que}$ stionnaire.pdf, diakses Tanggal 1 September 2018.

2005. Attitudes, Personality and Behavior. Second Edition. England: Open University Press.
Albrecht et Al. 2008. Fraud Examination. Third Edition. South Western College Pub.

Atmoko, Tjipto. 2006. Standar Operasional Prosedur (SOP) dan Akuntabilitas Kinerja Instansi Pemerintah. Jurnal Governance: Sinergi Masyarakat, Swasta dan Pemerintah yang Berkeadilan. Vol.2, No.2, Hal.56-59.

Emzir. 2010. Metodologi Penelitian Kualitatif: Analisis Data. Jakarta: Rajawali Pers.

Fitria, Titi Darmaningtyas. 2009. Pelaksanaan Penyelesaian Keberatan Wajib Pajak Di Kantor Wilayah Direktorat Jenderal Pajak Daerah Istimewa Yogyakarta. Skripsi S1. Universitas Islam Indonesia. Yogyakarta. Tidak dipublikasikan.

Indrajaya, Rendy Okta dan Gustin Tanggulungan. 2012. Pengujian Efektivitas Sop Pelayanan di Kantor Pelayanan Perizinan Terpadu Kota Salatiga Dengan Tehnik Audit Kepatuhan. Institutional Repository. Diambil dari http://repository.library.uksw.edu/brows e?order=ASC\&rpp=20\&sort_by $=-$ $1 \&$ value $=$ Tanggulungan $\% 2 \mathrm{C}+$ Gustin \&e tal $=-1 \&$ offset $=20 \&$ type $=$ author

KPP Pratama Kendari, 2018. Rekapitulasi Data Penyelesaian Permohonan Keberatan Tahun 2017. Kendari: Kantor Pelayanan Pajak Pratama Kendari.

Mahmudi. 2010. Analisis Laporan Keuangan Pemerintah Daerah. Yogyakarta: Sekolah Tinggi Ilmu Manajemen.

Moleong, L. J. 2005. Metodologi Penelitian Kualitatif. Bandung: Rosda.

Pramudijono. 2009. Pengaruh Program Kemitraan Terhadap Kepatuhan Wajib Pajak dengan Kinerja Organisasi Sebagai Variabel Intervening. Tesis S2. Universitas Gajah Mada. Yogyakarta. Tidak dipublikasikan.

Putra, Randy Ariyadita. 2015. Pelaksanaan Standard Operating Procedure (SOP) penyelesaian permohonan keberatan di Kantor Wilayah Direktorat Jenderal 
Pajak Daerah Istimewa Yogyakarta. Tesis S2. Universitas Islam Indonesia. Tidak dipublikasikan.

Putra, Randy Ariyadita. 2018. Interview oleh Oky Cahya Kurniawan. Alat perekam. 19 Oktober. Universitas Nahdlatul Ulama Sulawesi Tenggara, Kendari. . 2018. Interview oleh Candra Dista. Alat perekam. 19 Oktober. Universitas Nahdlatul Ulama Sulawesi Tenggara, Kendari. . 2018. Interview oleh Arianti. Alat perekam. 5 November. Universitas Nahdlatul Ulama Sulawesi Tenggara, Kendari.

2018. Interview oleh Eka. Alat perekam. 5 November. Universitas Nahdlatul Ulama Sulawesi Tenggara, Kendari.

Satori, Djam'an dan Aan Komariah. 2009. Metodologi Penelitian Kualitati. Bandung: Alfabeta.

Siagian, P.S. 2008. Manajemen Sumber Daya Manusia. Jakarta: Bumi Aksara.

Suandy, Erly. 2011. Perencanaan Pajak. Edisi 5. Jakarta: Salemba Empat.

Sugiyono. 2008. Metode Penelitian Kuantitatif, Kualitatif dan $R \quad \& \quad D$. Bandung: Alfabeta.

2009. Memahami Penelitian Kualitatif. Bandung: Alfabeta.

2014. Memahami Penelitian Kualitatif. Bandung; Alfabeta.

Suparmoko. 2000. Keuangan Negara Dalam Teori dan Praktek. Edisi 5. Yogyakarta: BPFE.

Surat Edaran Direktur Jenderal Pajak Nomor SE-11/PJ/2014 Tentang Petunjuk Pelaksanaan Penyelesaian Keberatan PPh, PPN dan/atau PPnBM.

Undang-Undang Dasar Negara Republik Indonesia Tahun 1945.

Undang-Undang Nomor 6 Tahun 1983 tentang Ketentuan Umum dan Tata Cara Perpajakan Sebagaimana Telah
Beberapa Kali Diubah Terakhir Dengan Undang-Undang Nomor 16 Tahun 2009.

Undang-Undang Nomor 14 Tahun 2002 Tentang Pengadilan Pajak.

Zuraida, Ida dan LY. Hari Sih Advianto. 2011. Penagihan Pajak (Pajak Pusat dan Pajak Daerah). Bogor: Ghalia Indonesia. 